\title{
Comparison of Five DNA Extraction Methods for Detection of Leaf Scald in Sugarcane Through PCR
}

\author{
Vanessa Duarte Dias ${ }^{1 *}$, Geisiane Alves Rocha1, Erico de Campos Dianese ${ }^{1}$, Luiz Artur Mendes Bataus ${ }^{2}$ and Marcos Gomes \\ da Cunha ${ }^{1}$ \\ ${ }^{1}$ Department of pathology, Federal University of Goiás, Brazil \\ ${ }^{2}$ Department of Bechemistry and Molecular Biology, Federal University of Goiás, Brazil \\ *Corresponding author: Vanessa Duarte Dias, Department of pathology, Federal University of Goiás, Brazil
}

Received: 眥 November 19, 2019

Published: 侮 December 05, 2019

\begin{abstract}
Among the techniques used for Leaf Scald diagnosis, PCR is considered the most sensitive, however this technique has limitations for use in large-scale analysis, particularly because of the difficulty/complexity associated with DNA extraction. Detection success largely depends upon the host species and the protocol used for DNA extraction. Here we describe a comparison of five DNA extraction methods and determine which one is more efficient for large scale detection of Leaf Scald through PCR. DNA extraction was performed from:

a. Bacterial culture;

b. Bacterial culture added to the vascular fluid from sugarcane; and

c. From infected plant stalks. Of the five methods tested, three were effective for large-scale detection by PCR.
\end{abstract}

Keywords: Xanthomonas albilineans, molecular detection, DNA extraction, large scale detection

\section{Introduction}

The sugarcane cultivation in Brazil is expanding. The production area has increased considerably in 2011, most significantly in the states of Minas Gerais (83,100 ha), Mato Grosso do Sul (84,700 ha), Goiás (79,110 ha) and Mato Grosso (13 040 ha) Conab-Companhia Nacional de Abastecimento [1]. In these states, besides increasing the crop area, new processing plants began operating in the last cropping season. Even with those investments, the domestic production by the sugarcane industry in $2011 / 2012$ was $8.4 \%$ lower than in previous years. This decrease was due to a number of factors. Among them, sanitary problems are remarkable, with increased incidence of sugarcane diseases. The producers have increased the number of cultivated areas to minimize reduction in productivity. The expansion resulted in the multiplication of sugarcane grown areas with no control or treatment of diseases. According to Gatti, sugarcane diseases are very serious; since they cause cultivar degeneration, requiring periodic replacement of crops. Leaf scald is one of the most important worldwide diseases of sugarcane Birch [2]. Xanthomonas albilineans, the causal agent of Leaf Scald, has great destructive potential, capable of causing stalk malformation and tillers death, with subsequent reduction in sucrose content and yield losses. When the disease is present in extremely susceptible cultivars, it may cause losses of up to $100 \%$ Tokeshi and Rago [3].

In most cases the symptoms of this disease are not visually noticeable, particularly due to latent infections. Thus, bacteria multiply and spread without being detected, especially in the beginning of the plant cycle Comstock and Irey [4]. Besides that, symptoms that occur in a more visible way may show variations, which may happen due to factors related to climate and plant nutrition Tokeshi and Rago [3]. Those variations of symptoms make the diagnosis even more difficult, requiring the use of more precise techniques of detection, such as serological and/or molecular methods Pan et al. [5]; Tokeshi and Rago [3]. The detection of Leaf scald by serological techniques is effective when the bacteria reach high concentrations in the tissue; by this time, the production is already potentially lost and the pathogen disseminated to other plants Honeycutt et al. [6]. PCR (Polymerase Chain Reaction) sensibility is higher and more effective than serological techniques, 
detecting contaminations in samples with less than 20 UFC of X. albilineans, whereas serological techniques as DIA (Dot immunobinding Assay) and ELISA (Enzime Linked immunosorbent Assay) requires populations of 106 UFC mL-1 and 105 UFC mL-1, respectively Wang et al. [7]. PCR is the most sensitive technique available, but it has some hindrances because it requires elaborated protocols to extract DNA with high degree of purity, which hampers the short time analysis of a high number of samples. Therefore, the objectives of this work were to compare five fast DNA extraction methods, determine the more efficient method and perform the necessary adjustments for large scale detection of X. albilineans by PCR.

\section{Material and Methods}

\section{Bacteria and infected plant stalks}

X. albilineans was obtained from Instituto Agronômico de Campinas (IAC) and grown in Wilbrink medium ( $5 \mathrm{~g}$ of bactopeptone, $10 \mathrm{~g}$ of sucrose, $0,5 \mathrm{~g}$ of $\mathrm{K} 2 \mathrm{PO} 4.3 \mathrm{H}_{2} \mathrm{O}, 0,25 \mathrm{~g}$ of $\mathrm{Mg} \mathrm{SO}_{4} \cdot 7 \mathrm{H}_{2} \mathrm{O}, 0,05 \mathrm{~g}$ of $\mathrm{Na}_{2} \mathrm{SO}_{3}$ and $15 \mathrm{~g}$ of Agar for 1 liter of culture medium). Infected sugarcane stalks were taken from experimental plots belonging to RIDESA (Rede Interuniversitária para o Desenvolvinento do Setor Sucroenergético) at Jales Machado Processing Plant, in Goianésia - GO. The infection was confirmed prior to the mailing of these samples through

\section{Symptom Analysis}

\section{Vascular fluid of sugarcane plants}

Primarily, a transversal cut was performed on the lower portions and another on the upper portion of the stalks base (between the second and third internodes). Afterwards, sap from the xylem was extracted using a low pressure compressor connected to a rubber teat cup (used in milking machines) on the hose end Gao et al. [8]. From each stalk sampled, approximately $0.3 \mathrm{~mL}$ of vascular fluid were obtained and transferred to $1.5 \mathrm{~mL}$ microtubes in which two drops of quaternary ammonia at $0.2 \%$ or chloroxidine dicluconate at $2 \%$ were added Pan et al. [5].

\section{DNA extraction methods}

Table 1: Methods of DNA extraction based on different types of buffers.

\begin{tabular}{|c|c|c|}
\hline Method & Protocol & Buffer \\
\hline M1 & Alsubel [16] & CTAB \\
\hline M2 & Davis et al. [17] & TAE \\
\hline M3 & Gomes et al. [18] & FENOL \\
\hline M4 & Adapted from Ogram and Gary [21] & TE + SDS \\
\hline M5 & Gao et al. [8] & NaOH+Tween 20 \\
\hline
\end{tabular}

Five methods of DNA extraction were tested (Table 1). All DNA extraction methods followed the original protocols, except the fourth, named M4, which was performed according to the following modifications: the initial $160 \mu \mathrm{L}$ was centrifuged at 10,000 RPM for 10 minutes and the supernatants were discarded. The pellet was resuspended in $500 \mu \mathrm{L}$ of Tris-EDTA (Tris $50 \mathrm{mM}$ and EDTA $1 \mathrm{mM}$ ) + $2 \%$ SDS; mixed with a vortex and boiled for 5 minutes. After cooling at room temperature, $50 \mu \mathrm{L}$ of $3 \mathrm{M} \mathrm{NaCl}$ were added; samples were mixed with a vortex and $1 \mu \mathrm{L}$ of $100 \%$ ethanol was added. Mixtures were incubated at $-200 \mathrm{C}$ for 30 minutes followed by centrifugation at 10,000 RPM for 10 minutes at room temperature. The supernatant was discarded and the pellet resuspended in $100 \mu \mathrm{L}$ Milli-Q water. DNA extractions were performed from three distinct sources:

a. Bacterial culture (BC)-X. albilineans cells were transferred from Wilbrink media to $15 \mathrm{~mL}$ tubes containing $2.5 \mathrm{~mL}$ of Milli- $\mathrm{Q}$ autoclaved water. The bacterial suspension was homogenized in vortex and aliquots of $160 \mu \mathrm{L}$ were transferred to $1,5 \mathrm{~mL}$ microtubes for further use. Each DNA extraction method was made in triplicate. To quantify the total number of bacterial cells used in the extraction, $1 \mu \mathrm{L}$ of this suspension was subjected to a dilution series of $10^{-1}$ to $10-5$ in a sterile saline solution $(0.85 \% \mathrm{NaCl})$. Ten microliters of each dilution were placed in the center of Petri dishes with $60 \mathrm{~mm}$ of diameter containing Wilbrink media. Bacterial culture added to the vascular fluid of sugarcane (BF); $10 \mu \mathrm{L}$ of the bacterial suspension were transferred to a microtube containing $150 \mu \mathrm{L}$ of vascular fluid from uninfected sugarcane. The vascular fluid was obtained from five sugarcane cultivars (RB 952857, RB 925211, RB 925345, RB 867515 and RB 72454).

b. From infected plant stalks (IPS); vascular fluid from sugarcane stalks naturally infected with X. albilineans were extracted according to the previously described methodology. Fifteen samples were obtained from the basal portion of these stalks to test the five DNA extraction methods.

After the extraction, the DNA samples were quantified and the purity was determined by reading the absorbance at $260 \mathrm{~nm}$ and 280nm, using an Amershan Pharmacia Biotec spectrophotometer (UV-Vis Ultraspec ( 3000 Pro). The ratio of absorbance at $260 \mathrm{~nm}$ and $280 \mathrm{~nm}$ was used to assess the purity of DNA. Specific PCR for X. albilineans detection. The PCRs with $20 \mu \mathrm{L}$ of final volume were composed by $1 \mu \mathrm{L}$ of DNA, polymerase buffer ( $50 \mathrm{mM} \mathrm{KCl}$; $10 \mathrm{mM}$ Tris- $\mathrm{HCl} \mathrm{pH} 8.3$ ), $0.8 \mathrm{mM} \mathrm{MgCl} 2,0.2 \mathrm{mM}$ of each dNTPs, $1.0 \mu \mathrm{M}$ of oligonucleotide PGBL1 (5'CTTTGG GTC TGT AGC TCA GG) and PGBL2 (5'GCC TCA AGG TCA TAT TCA GC), which amplified the ITS regions of the 16S-23S rDNA Pan et al. [5] and one unit of Taq DNA polymerase (Invitrogen). Amplification conditions comprised of one cycle of denaturation at 950C for 5 minutes followed by 35 cycles at 950C for 30 seconds, annealing at 570C for thirty seconds, extension for thirty seconds, and final extension at $720 \mathrm{C}$ for ten minutes. Following the amplification, the PCR products were analyzed by $1.5 \%$ agarose gel electrophoresis and stained with Gel Red reagent (Invitrogen). 


\section{Results and Discussion}

The efficacy of commercial kits for DNA extraction was not tested in this work, since its use in large scale analyses is economically unfeasible. These kits are generally faster than the CTAB and phenol methods; however, the cost is very high Demeke and Jenkins [9]. Real Time PCR (qPCR) is also expensive and not yet suitable for routine diagnosis tests for a large number of samples Urashima and Grachet [10]. Extraction protocols using cetil trimethyl ammonium bromide (CTAB) were widely used to extract DNA from leaves, seeds, grains, and processed food. The procedure, although efficient, is time consuming and uses hazardous chemical products, such as phenol and chloroform Demeke and Jenkins [9]. Urashima and Zavaglia [11] tested the detection of X. albilineans in vascular fluid of contaminated sugarcane by PCR using a CTAB protocol Murray and Thompson [12]. The DNA extraction step takes around 24 hours; making large scale analysis much more costly and time consuming. In this work we describe a comparison of five methods of DNA extraction and evaluate which one is more efficient for large scale detection of Leaf scald through PCR. DNA extraction was performed from: a) Bacterial culture - BC; b) Bacterial culture added to the vascular fluid from sugarcane BF; and c) From infected plant stalks - IPS. All procedures were performed in triplicate.

Table 2: DNA quantification and purity. Concentration is expressed as $\mathrm{mg} / \mathrm{mL}$. The ratio of absorbance at $260 \mathrm{~nm}$ and $280 \mathrm{~nm}$ was used to assess the purity of DNA.

\begin{tabular}{|c|c|c|c|c|c|c|c|}
\hline Methods & BC Conc & BC Purity & BF conc & BF Purity & IPS Conc & IPS Purity & Mean \\
\hline M1 & 4.83 & ND & 4.8 & 2.64 & 1.83 & ND & 3.82 \\
\hline M2 & 15.17 & 2.98 & 32.5 & 1.76 & 102.83 & 1.46 & 50.16 \\
\hline M3 & 0.33 & ND & 1.3 & ND & 15.33 & 0.58 & 5.65 \\
\hline M4 & 12.33 & 1.94 & 6.9 & 1.64 & 36.17 & 1.53 & 18.46 \\
\hline M5 & 8.17 & 8.33 & 163.7 & 1.57 & 347.83 & 1.28 & 173.23 \\
\hline
\end{tabular}

Quantification of DNA samples was estimated by spectrophotometric measurement. Table 2 shows the yield and purity of DNA extracted from each source, using the five methods. A large variation can be observed in DNA yield of each source according to each method. The concentration ranged from 0.33 to $15.17 \mathrm{mg} / \mathrm{mL}$ (BC); from 1.30 to $163.70 \mathrm{mg} / \mathrm{mL}$ (BF); and from 1.83 to $347.83 \mathrm{mg} / \mathrm{mL}$ (IPS). Methods M1 and M3 resulted in a lower amount of DNA concentration. This low concentration did not allow a precise calculation of purity levels. The M5 showed the best yield, but DNA obtained did not show an acceptable level of purity (ranged between 1.28 to 8.33). The M4 allowed the obtainment of DNA with acceptable level of purity, were the ratio was within expected values (1.53 to 1.94). The effectiveness of PCR may be affected by extraction methodology and by DNA source. Then, obtained DNA samples were used to test the influence of these variables. PCR products analysis showed that extraction methods have influence on the effectiveness of PCR. Figure 1 a) shows the influence of the extraction methods studied using BC as source of DNA. All tested methods resulted in amplifications, except for M2.
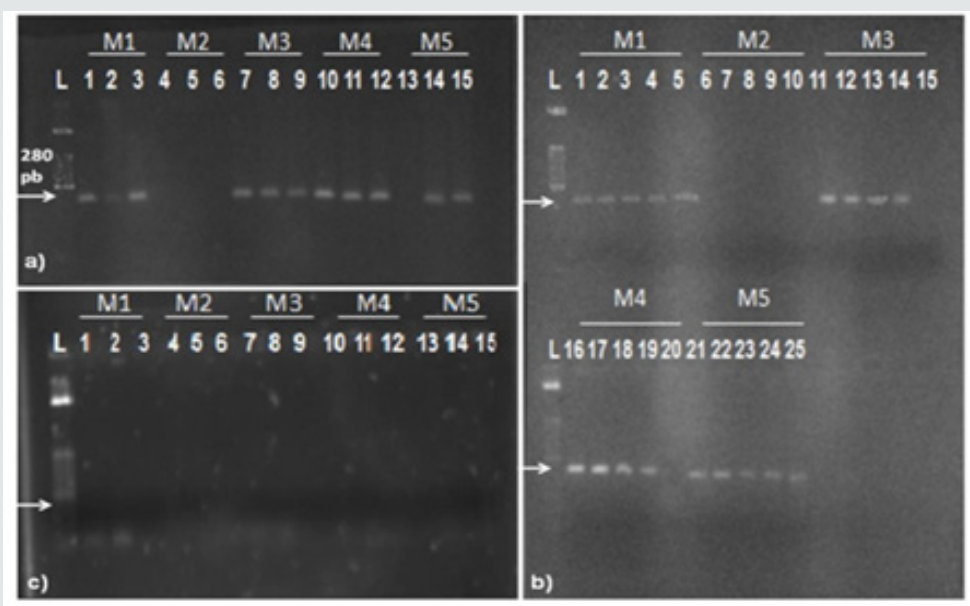

Figure 1: Products of PCR from samples originated from:

a) pure bacterial cultures;

b) vascular fluids from cultivars RB 952857, RB 925211, RB 925345, RB 867515 and RB 72454 with further addition of Xanthomonas albilineans;

c) from infected plant stalks. $L=50$ bp marker. White traces represent the replicates of each method of extraction, and the code above each one indicates the DNA extraction methods used (M1 to M5). Arrows indicate the expected band height $288 \mathrm{pb}$ ). 
The influence of differences in vascular fluid of five cultivars of sugarcane on the efficiency of PCR can be observed in Figure 1-b. From all vascular fluid of different sugarcane cultivars tested, only one showed no reproducibility (RB 72454). Using DNA obtained by M1 and M5, PCR products were observed, but using DNA from M3 and M4 the amplification failed. Gao et al. [8] reported that vascular fluids from different cultivars of sugarcane can inhibit PCR, according to their work related with the detection of Leifsonia xyli subsp. xyli by PCR. Thirty-one cultivars of sugarcane were studied, nine were from the USA and 22 were from China. Nineteen cultivars (61.3\%), tested positive by PCR, while $93.5 \%$ were positive by dot-blot enzyme immunoassay detection. This result showed the importance to evaluate the influence of nucleic acid extraction methods and the influence of different vascular fluid sources on the result of the PCR assay. Again, PCR failed for M2. M2 was effective in extracting DNA, resulting in significant quantities, however the DNA obtained by this method failed in all attempts of amplification. This result agrees with the idea that DNA extraction methodology is critical to the success of PCR Wilson et al. [13]. All assays using DNA obtained from IPS failed, no amplification products were observed Figure 1-c. The absence of amplification in all samples from IPS may be explained by the presence of PCR inhibitors in those samples. Some polysaccharides (from the plant) may act in the inhibition of the amplification of the target sequence. Many authors have reported the inhibitory action of carbohydrates on PCR Ferreira and Grattapaglia, Jaueerally-Fakin et al. [14]. Another possibility is the presence of substances in the rough extract of sugarcane with inhibitory capability of the Taq DNA polymerase, a fact that has been described by Pan et al. [5].
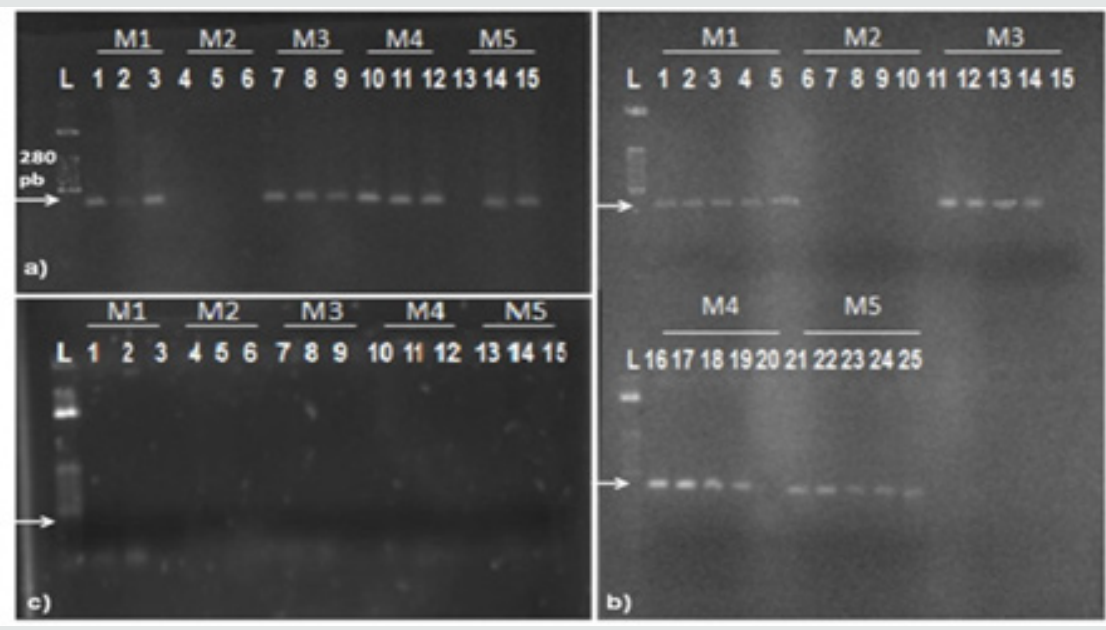

Figure 2: Amplification of DNA extracted from sugarcane broth with Leaf Scald;

a) amplifications from DNAs diluted in 10-1 obtained by methods M1, through M5;

b) amplifications from DNAs diluted in 10-2 obtained by methods M1, through M5;

c) amplifications from DNAs diluted in 10-3 performed by methods M1, through M5;

d) amplifications from DNAs diluted in 10-4 performed by methods M1, through M5.

Since all assays using DNA from IPS failed, DNA obtained from this source was subjected to serial dilutions (10-1 to 10-4) to evaluate the effect on the PCR assay. PCR products analysis showed that dilutions have a strong influence on the effectiveness of PCR. PCR from IPS showed significant improvement after DNA dilution Figure 2 . The dilution at $10-3$ resulted in $100 \%$ of amplifications Figure 2-c and all reactions for the dilutions in question were repeated five times to test reproducibility. Results were identical for all reactions. Thereby, it was verified that PCR from diluted products of DNA, besides providing $100 \%$ of detection for all DNA methods of extraction, also achieved reproducibility. Difficulties in PCR assays using DNA from vascular fluid samples of sugarcane have been reported in the literature. Pan et al. [15] developed a protocol to detect X. albilineans by PCR using oligonucleotides ALA4 and L1; however, the protocol amplified bands of different sizes. In the following work the same authors devised highly specific oligonucleotides. PCR were carried out directly from vascular fluid of sugarcane and amplification results were not consistent Pan et al. [5]. These studies showed the influence of sugarcane's vascular fluid on the effectiveness of PCR. Few studies have been conducted regarding PCR feasibility directly from vascular fluid over the years Comstock and Irey [4] Lopes et al. [15] Wang et al. [7]. Results from this work shows that fast methods of DNA extraction, which took approximately 2 hours for a total of 100 samples, may be as effective as more time-demanding and elaborated protocols that require around 24 hours to complete [16-20]. Therefore, large scale diagnosis of leaf scald in sugarcane may be performed through the DNA extraction techniques M2, M4 or M5, since these methods are fast, simple and do not use phenol as one of its reagents[21-23].

\section{References}

1. Porto SI, Oliveira Neto AA, Sousa FOB (2012) Conab-Companhia Nacional De Abastecimento. Avaliação da safra agrícola de cana-de-açúcar. 3oㅡ Levantamento da safra 2012. Internet Resource. 
2. Birch RG (2001) Xanthomonas albilineans and the antipathogenesis approach to disease control. Molecular Plant Pathol 2: 1-11.

3. Tokeshi H, Rago A (2005) Doenças da Cana-de-açúcar. In: kimati h, amorim l, rezende, JAM.; bergamin filho a, Camargo, LEA (eds). Manual de Fitopatologia. São Paulo, Piracicaba, pp.197-223.

4. Comstock JC, Irey MS (1992) Detection of the sugarcane leaf scald pathogen Xanthomonas albilineans, using tissue blot immunoassay, ELISA, and isolation techiniques. Plant Disease 76: 1033-1035.

5. Pan YB, Grisham MP, Burner DM, Legendre BL, Wei Q (1999) Development of Polymerase Chain Reaction Primers Highly Specific for Xanthomonas albilneans, the causal Bacterium of sugarcane Leaf Scald disease. Plant Disease 83: 218-222.

6. Honeycutt RJ, Sobral BWS, Mcclelland M (1995) tRNA intergeneric spacers reveal polymorphysms diagnostic for Xanthomonas albilineans. Microbiol 141: 3229-3239.

7. Wang ZK, Comstock JC, Hatziloukas E, Shaad NW (1999) Comparasion of PCR, Bio-PCR, DIA, ELISA and isolation on semiselective medium for detection of, the causal agent of leaf scald of sugarcane. Plant Pahol 48(2): $245-252$.

8. Gao SJ, Pan YB, Chen RK, Chen PH, Zhang H, et al. (2008) Quick detection of Leifsonia xyli subsp. xyli by PCR and nucleotide sequence analysis of PCR amplicons from Chinese Leifsonia xyli subsp. xyli isolates. Sugar Tech 10: 334-340.

9. Demeke T, Jenkins G (2010) Influence of DNA extraction methods, PCR inhibitors and quantification methods on real-time PCR assay of biotechnology-derived traits. Anal and Bioanal Chem 396: 1977-1990.

10. Urashima AS, Grachet NG (2012) Métodos de detecção de Leifsonia xyli subsp. xyli e efeito da termoterapia na brotação das gemas de diferentes variedades de cana-de-açúcar. Tropical Plant Pathol 37(1): 57-64.

11. Urashima AS, Zavaglia AC (2012) Comparação de dois métodos diagnósticos de escaldadura-das-folhas (Xanthomonas albilineans) da cana-de-açúcar. Summa Phytopathologica 38(2): 155-158.

12. Murray MG, Thompson WF (1980) Rapid isolation of high molecular weight plant DNA. Nucleic Acids Research 8: 4321-4325.

13. Wilson D, Yen-Lieberman B, Reischl U, Warshawsky I, Procop GW (2004) Comparison of five methods for extraction of Legionella pneumophila from respiratory specimens. J Clin Microbiol 42: 5913-5916.

14. Jaueerally Fakin Y, Autrey JC, Daniels MJ, Dookun A (2002) Genetic polymorphism among Xanthomonas albilineans strains, using a single oligonucleotide primer. European J of Plant Pathol 108: 121-130.

15. Pan YB, Grisham M, Burner DM (1997) A Polymerase Chain Reaction Protocol for the Detection of Xanthomonas albilineans, the Causal Agent of Sugarcane Leaf Scald Disease. Plant Disease 81:189-194.

16. Alsubel FN (1992) Short protocols in molecular biology. John Wiley New York, USA.

17. Davis MJ, Rott $P$, Warmuth CJ, Chatenet M, Baudin P (1997) Intraspecific genomic variation within Xanthomonas albilineans, the sugarcane leaf scald pathogen. Phytopathol 87: 316-324.

18. Gomes LH, Duarte KMR, Andrino FG, Tavares FCA (2000) A Simple Method For DNA Isolation From Xanthomonas spp. Scientia Agricola 57: 553-555.

19. Lopes SA, Damann KE, Grelen LB (1998) Comparison of methods for identification of sugarcane pathogen Xanthomonas albilineans. Summa Phytopathologica 24: 114-119.

20. Marcuz FS, Souto ER, Vieira RA, Marrafon MA, Barboza AAL, et al. (2009) Levantamento da incidência de Leifsonia xyli subsp. xyli em plantios de cana-de-açúcar do noroeste do Paraná. Ciênc. Agrotec 33: 1935-1939.

21. Ogram A, Gary SS (1987) The extraction and purification of microbial DNA from sediments. J of Microbiol Methods 7: 57-66.

22. Schneider S, Smith T, hansen U (2011) SCOREM: statistical consolidation of redundant expression measures. Nucleic Acids Research 40(6): e46.

23. Thompson J, Higgins D, Gibson T (1994) CLUSTAL W:Improving the sensitivity of progressive multiple sequence alignment though sequence wighting, position-specific gap penalties and weitht matrix choice. Nucleic Acids Research 22(22): 4673-4680.
This work is licensed under Creative Commons Attribution 4.0 License To Submit Your Article Click Here: Submit Article

DOI: $10.32474 /$ CIACR.2019.08.000278

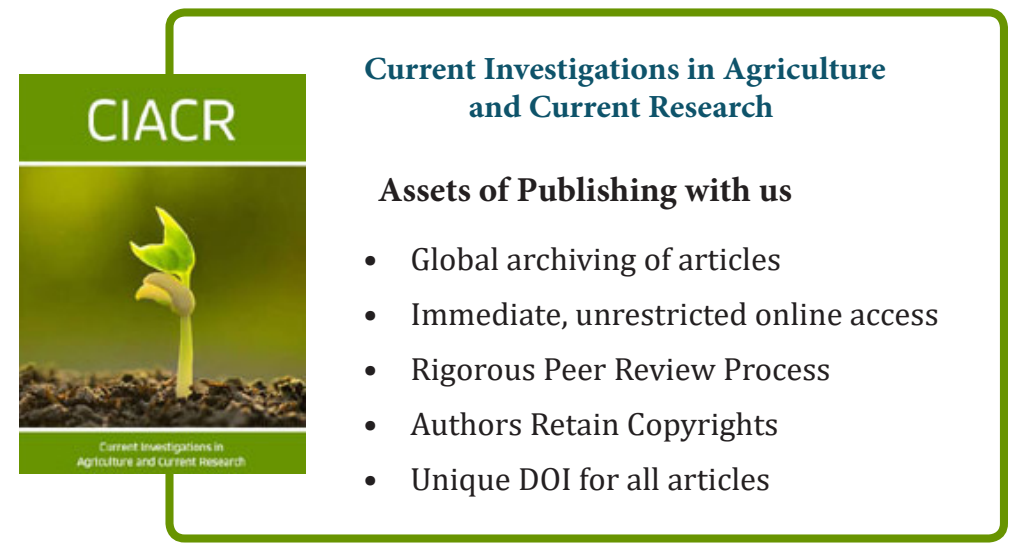

